\title{
The legal framework for delegated and implementing powers ten years after the entry into force of the Lisbon Treaty
}

\author{
Merijn Chamon ${ }^{1,2}$
}

Accepted: 14 December 2020 / Published online: 12 January 2021

(C) The Author(s) 2021

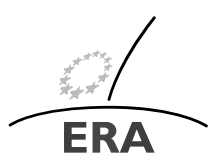

EUROPÄISCHE RECHTSAKADEMIE ACADEMY OF EUROPEAN LAW ACADEMIE DE DROIT EUROPEEN ACCADEMIA DI DIRITTO EUROPEO TRIER - TREVES - TREVIRI

\begin{abstract}
This Article gives an overview of the legal framework governing the exercise of the delegated and implementing powers foreseen in Articles 290 and 291 TFEU in light of the most recent jurisprudence of the EU Courts in this field. It clarifies what essential elements are under Article 290 TFEU, how the Courts test this requirement and how it relates to the requirement under Article 290 TFEU that a delegation must also be specific. The article subsequently discusses and compares the control regimes in place under Articles 290 and 291 TFEU, noting that in postLisbon institutional practice they have evolved towards each other. Linked to this is the question how delegated and implementing powers differ. In light of the Court's jurisprudence the article concludes that it is up to the legislature to make this distinction and that the legislature can also create executive powers outside the framework of Articles 290 and 291 TFEU and grant them to EU agencies. The article concludes by flagging some open questions which the Court has not resolved yet.
\end{abstract}

Keywords Article 290 TFEU • Article 291 TFEU · Delegated powers · Implementing powers $\cdot$ Essential elements $\cdot$ Judicial review $\cdot$ EU agencies

\section{Introduction}

This article provides a summary of two presentations given during the ERA Online Seminar on 'Delegated and Implementing Powers in Practice' on 10 November 2020. In light of the word count constraints it is impossible to develop the legal framework

\footnotetext{
M. Chamon

m.chamon@maastrichtuniversity.nl

1 Assistant Professor of EU Law, Maastricht University, Maastricht, The Netherlands

2 Visiting Professor, College of Europe, Bruges, Belgium
} 
of executive rulemaking in the EU in detail. This article will therefore restrict itself to sketching the legal framework as laid down in primary law and discussing the take home messages of the most significant judgments of the Court of Justice and the General Court. Further, key developments at the level of secondary legislation will be addressed and a number of open questions, not yet resolved through political compromise or judicial decisions, will be flagged.

\section{The legal framework under the Lisbon Treaty}

The natural starting point for discussing delegated and implementing powers might seem to be the Lisbon Treaty, since it is that treaty, which entered into force on the first of December 2009, that introduced the concepts of implementing and delegated acts in EU law. Yet a full and in-depth understanding of the Lisbon framework itself presupposes an understanding of the pre-Lisbon legal framework governing (what was then simply called) 'implementing powers'. Indeed, the Lisbon reform in the area of executive rulemaking does not signify a radical break with the pre-Lisbon past but rather builds on it and should be seen as part of a bigger evolution in adapting the legal framework to both practical experiences built up over the years and shifting political power relations. While an elaborate discussion of the pre-Lisbon framework(s) would thus have its uses, this article will still take the text of the Lisbon Treaty as a starting point in light of the constraints of space and the fact that knowledge of the pre-Lisbon era, while useful, is not indispensable to acquire a basic understanding of the current legal framework. ${ }^{1}$

\subsection{The introduction of different acts}

While the precursor to Article 288 TFEU already since 1958 identified the three main instruments through which the EU institutions may adopt binding law (i.e. regulations, directives, decisions), the EU's primary law did not make an explicit distinction between the different acts which the EU institutions adopt. In the 1970's seminal Köster case, the Court of Justice did clarify that a distinction should be made between basic acts that are adopted pursuant to a legal basis in the Treaties, and implementing acts which are adopted pursuant to legal bases to be found in basic acts. ${ }^{2}$ This simplicity was abandoned by the Lisbon Treaty which introduced a distinction, through Articles 289, 290, and 291 TFEU between legislative, delegated and implementing acts. The contemporary delegated and implementing acts correspond to the

\footnotetext{
${ }^{1}$ Readers interested in the developments up until the Lisbon Treaty are directed to other works, e.g. Christoph Bertram, 'Decision-Making in the E.E.C.: the Management Committee Procedure', (1968) 5 Common Market Law Review 3, pp. 246-264; Claude Blumann, 'La Comitologie: l'exercice de la fonction exécutive dans la Communauté européenne', in C. Engel and W. Wessels (eds.), From Luxembourg to Maastricht: institutional change in the European Community after the single European act, Bonn, Europa Union, 1992, pp. 89-108; R. Pedler and G. Schaefer (eds.), Shaping European Law and Policy: The Role of Committees and Comitology in the Political Process, Maastricht, European Institute of Public Administration, 1996; Carl Fredrik Bergström, Comitology—Delegation of Powers in the European Union and the Committee System, Oxford, OUP, 2005, 428 p.

${ }^{2}$ Case 25/70, Köster, ECLI:EU:C:1970:115, para. 6.
} 
pre-Lisbon 'implementing acts' since they are adopted pursuant to an empowerment delegated or conferred in an act of secondary legislation. The new category of legislative acts in turn does not completely correspond to the pre-Lisbon 'basic acts'. This is because Article 289 TFEU gives a procedural definition of what constitutes a legislative act: "Legal acts adopted by legislative procedure shall constitute legislative acts." 3 Whether a legal act is adopted by legislative procedure is in turn determined by the procedure prescribed by that legal act's legal basis. If the legal basis refers to the ordinary legislative procedure or a special legislative procedure, ${ }^{4}$ the act to be adopted will be a legislative act. The reason why the contemporary legislative acts do not correspond neatly with the pre-Lisbon basic acts is because not all the provisions of the EU Treaties that allow for the adoption of legal acts prescribe that these acts must be adopted through (the ordinary or one of the special) legislative procedure(s). Indeed, even if abstraction is made of the Common Foreign and Security Policy where no legislative acts may be adopted, ${ }^{5}$ a significant number of legal bases in the Treaties do not prescribe a legislative procedure. ${ }^{6}$ These legal bases therefore do not grant legislative powers but also do not depend on a prior conferral or delegation of powers in legislative acts, meaning they confer autonomous executive powers on the Council or Commission. ${ }^{7}$ Because they are not of legislative nature, the requirements for legislative decision-making ${ }^{8}$ do not apply even though materially the acts adopted pursuant to these powers cannot be distinguished from formal legislative acts. This is in itself a problematic feature of the Lisbon reform and in those rare cases where a Treaty provision allows the very same material rules to be adopted either through a legislative procedure or pursuant to an autonomous executive power, ${ }^{9}$ this problem is exacerbated since the Council is seemingly left the choice either to act in a legislative or executive capacity. Figure 1 shows how the pre- and post-Lisbon acts align to eachother.

Although the introduction by the Treaty of Lisbon of different acts might give the impression that the Lisbon Treaty also introduced a hierarchy of norms governing the relationship between those acts, no such hierarchy results from the Treaty provisions. Evidently, there is a hierarchy between a delegated act and the legislative act which it

\footnotetext{
${ }^{3}$ The Court has confirmed this in Joined Cases C-643/15 and C-647/15, Slovakia \& Hungary $v$. Council, ECLI:EU:C:2017:631, para. 62. But see however Case C-77/11, Council v. Parliament, ECLI:EU:C:2013:559, para. 60.
}

${ }^{4}$ For an overview of all the legal bases referring to the ordinary legislative procedure and those referring to a special legislative procedure, see respectively Annex III and Annex IV to the Report by Rapporteurs Corbett and Méndez de Vigo on the Treaty of Lisbon, 29 January 2008, A6-0013/2008.

${ }^{5}$ See Article 24(1) TEU.

${ }^{6}$ See e.g. Articles 31, 42, 43(3), 70, 75 second paragraph, 107(3)(e), 112, 122(1), 122(2), 155(2) first paragraph, 213, 300(5), 315 second paragraph, 44, 96(2), 105(2) and (3), 106(3), 108(2) first paragraph, 108(4), 114(6), 134(3), 331(1) TFEU.

${ }^{7}$ This distinction goes back to the constitutional treaty and was already then criticized. See e.g. Paolo Stancanelli, 'Le système décisionnel de l'Union', in G. Amato, H. Bribosia and B. de Witte (eds), Genèse et destinée de la constitution européenne: commentaire du traité établissant une Constitution pour l'Europe à la lumière des travaux préparatoires et perspectives d'avenir, Bruxelles, Bruylant, 2007, p. 518.

${ }^{8}$ Notably the requirement for the Council to deliberate in public pursuant to Article 16(8) TEU and the requirements under Protocols 1 and 2.

${ }^{9}$ See Articles 203, 349 first paragraph and 352(1) TFEU. 


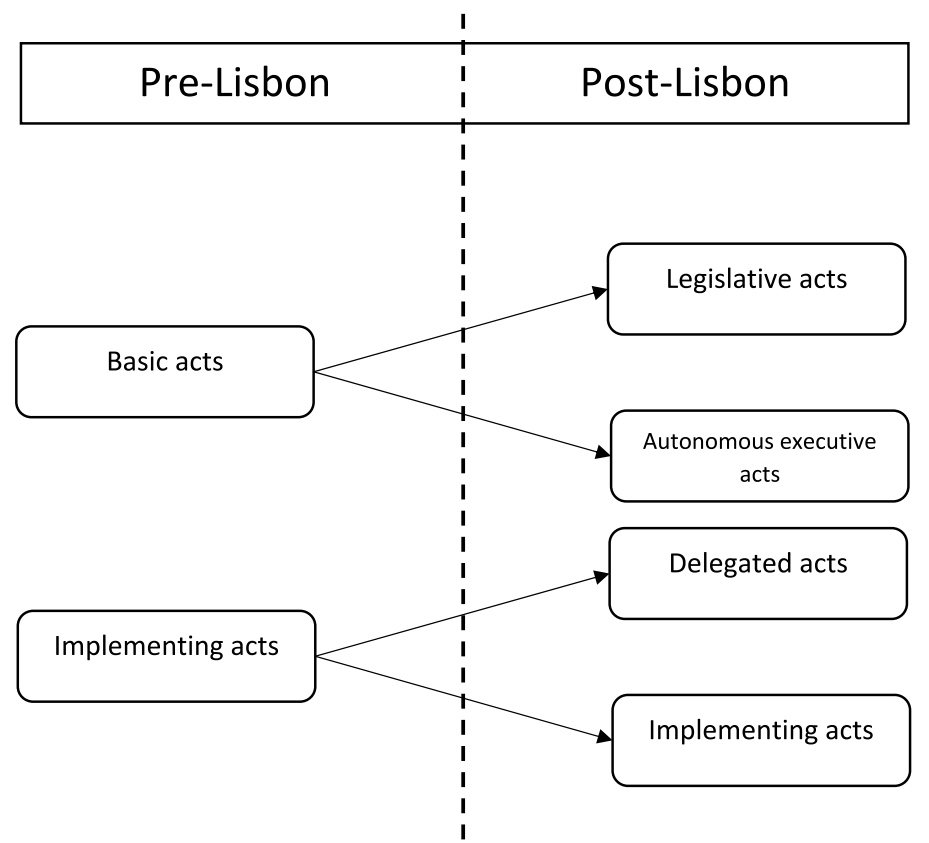

Fig. 1 Typology of acts

supplements or amends in the sense that the delegated act is only of equal rank to the legislative act in so far as the limits to the delegated power are respected; similarly an implementing act is inferior to the binding Union act which it implements. Apart from that there is no inherent hierarchy between legislative, delegated, implementing or autonomous executive acts. That an autonomous executive act can derogate from a legislative act has even been accepted by the Court of Justice. ${ }^{10}$

\section{Delegated and implementing acts: function}

As noted above, what used to be referred to as implementing acts in the pre-Lisbon era has been requalified under the Lisbon Treaty according to the function which different (pre-Lisbon) implementing acts fulfilled. After all, sometimes implementing acts were used to modify basic acts whereas generally they were used to apply basic acts. Even under the EU's pre-Lisbon constitutional framework, these two functions were fundamentally different (as they also are in national legal systems): when the Commission was empowered to modify a basic act it was exceptionally fulfilling a function which belonged to the 'legislator' (which of course was not qualified as such in the pre-Lisbon legal framework). The Commission's implementing acts then

${ }^{10}$ Joined Cases C-643/15 and C-647/15, Slovakia \& Hungary v. Council, ECLI:EU:C:2017:631, paras 7881. Seemingly contra, see Joined Cases C-124/13 and C-125/13, Parliament \& Commission v. Council, ECLI:EU:C:2015:790, para. 58. 
had an impact on the horizontal distribution of powers (between the EU institutions). When the Commission used implementing acts to apply basic acts, it was exceptionally fulfilling a function which normally the Member States fulfil in line with the EU's model of executive federalism. Those implementing acts had an impact on the vertical distribution of competences. Yet both types of implementing acts were subject to the same control regime established by the first and later the second comitology decisions (cf. infra).

The Lisbon Treaty translated these different functions into different acts: when the legislator wants to delegate the power to amend or supplement its legislation, it must give the Commission a delegated power as foreseen in Article 290 TFEU. When it is imperative that binding Union acts are implemented under uniform conditions, the Commission (or exceptionally the Council) must be given the power to adopt implementing acts as foreseen in Article 291(2) TFEU. The Court of Justice in its post-Lisbon caselaw also distinguished these functions as follows: "the purpose of granting a delegated power is to achieve the adoption of rules coming within the regulatory framework as defined by the basic legislative act ... By contrast, when the EU legislature confers an implementing power on the Commission on the basis of Article 291(2) TFEU, the Commission is called on to provide further detail in relation to the content of a legislative act, in order to ensure that it is implemented under uniform conditions in all Member States." 11 Yet, when exactly this threshold of the need for uniform conditions is met, remains unclear. ${ }^{12}$

\section{Delegated and implementing acts: limits}

Both the empowerments under Article 290 and 291 TFEU of course come with certain limits. Under Article 290 TFEU these are captured by the essentiality and specificity requirements which apply both to the legislator (when delegating powers) and to the Commission (when exercising a delegated power). The essentiality requirement thus prescribes that the legislature can only delegate a power to amend or supplement the non-essential elements of legislation. Conversely, when exercising a delegated power, the Commission cannot touch on the essential elements of legislation. Secondly, under the specificity requirement the legislature must explicitly define the objectives, content, scope and duration of the delegation of power. Conversely, when exercising a delegated power the Commission's mandate is circumscribed by these objectives, content, scope and duration. While the normative power of the Commission is essentially the same regardless whether it is empowered to amend or supplement legislation, the Court still noted that both powers should be clearly distinguished ${ }^{13}$ and that effectively if the Commission is not explicitly empowered to amend a legislative act it must be assumed that the delegated power is one to supplement the legislative act in question. ${ }^{14}$

\footnotetext{
${ }^{11}$ Case C-427/12, Commission v. Parliament \& Council, ECLI:EU:C:2014:170, paras 38-39.

${ }^{12}$ The EU Courts so far have not clarified this issue. The Court of Justice missed an opportunity to do so in Case C-146/13, Spain v. Parliament and Council, EU:C:2015:298.

${ }^{13}$ Case C-286/14, Parliament v. Commission, ECLI:EU:C:2016:183, para. 40.

${ }^{14}$ Ibid., paras 46-63.
} 


\subsection{The essentiality requirement under Article 290 TFEU}

That Article 290 TFEU prescribes the essentiality requirement as a strict limit to any delegation begs the question what the essential elements of legislation are and how they can be identified. In the Schengen Borders Code (SBC) case, the Commission and Council argued that it was up to the legislator itself to determine what it thought was (non-)essential. ${ }^{15}$ This issue would, as a result, not be justiciable. The Court however, borrowed from its standard legal basis test, ${ }^{16}$ and found that "which elements of a matter must be categorised as essential [...] must be based on objective factors amenable to judicial review." 17 While this statement itself is clear enough, its application in concrete cases is less straightforward also because the Court does not clearly identify the 'objective factors' and further reminds us that "the characteristics and particularities of the domain concerned" 18 must be taken into account. While that is undoubtedly the case, combined with the fact that no objective factors are identified, determining the essential elements risks becoming unpredictable. Indeed, the Court in $S B C$ simply arrives at the tautological conclusion that "provisions which, in order to be adopted, require political choices falling within the responsibilities of the European Union legislature cannot be delegated."19 What is essential is political and what is political is essential. In casu the Court ruled that the non-legislative measure of the Council indeed touched on essential elements given that it interfered with fundamental rights and the sovereign rights of third countries. ${ }^{20}$

This does not mean however that whenever a measure interferes with fundamental rights (or sovereign rights of third countries), recourse should be had to legislation. As Article 52(1) of the Charter makes clear, limitations should be provided for by law. This implies that they can be fleshed out in non-legislative acts as long as they are sufficiently provided for in legislation. ${ }^{21}$ The Court also confirmed this in the Europol case. The question in that case was whether the list of third countries with which Europol can set up cooperation should be defined by the legislator or not. The Parliament stressed the implications on fundamental rights of drawing up the list (transfers of data thereby being made possible between Europol and the third countries concerned). However, the Court accepted that the Council could draw up the list in its executive capacity, given that the legislature had sufficiently framed the power to draw up the list. ${ }^{22}$ Finally, without referring to the $S B C$ case, ${ }^{23}$ the Court in MultiAnnual Cod Plan noted that "measures which entail a policy choice [are] reserved to

\footnotetext{
${ }^{15}$ Case C-355/10, Parliament v. Council, ECLI:EU:C:2012:516, paras 45-46.

${ }^{16}$ See e.g. Opinion 2/00 re the Cartagena Protocol, ECLI:EU:C:2001:664, para. 22.

${ }^{17}$ Case C-355/10, Parliament v. Council, ECLI:EU:C:2012:516, para. 67.

${ }^{18}$ Ibid., para. 68 .

${ }^{19}$ Ibid., para. 65 .

${ }^{20}$ Ibid., para. 76.

${ }^{21}$ See also Joined Cases C-92/09 and C-93/09, Volker and Markus Schecke EU:C:2010:662, para. 66.

${ }^{22}$ See Case C-363/14, Parliament v. Council, ECLI:EU:C:2015:579, paras 50-51.

${ }^{23}$ That the Court did not refer to $S B C$ could be because it was asked to draw the dividing line between a legal basis conferring a legislative power and one conferring an autonomous executive power, rather than between a legislative act and a non-legislative act adopted pursuant to an empowerment in the legislative act.
} 
the EU legislature because the measures are necessary for the pursuit of the objectives of the common policies [at issue]." 24 What is essential therefore corresponds to what is political which is what is necessary to define a policy, which can arguably be determined in a 'top down approach': what is essential can be determined in an abstract way and subsequently be verified in a concrete case.

The question how to test this rather self-evident principle remains problematic and has already resulted in several decisions of the EU Courts. The underlying cases are typically first brought before the General Court (when a party challenges a Commission decision) and are not seldomly appealed before the Court of Justice which, on several occasions, has quashed and corrected the General Court's findings on the essentiality requirement of Article 290 TFEU. Constraints of space do not permit a fully fledged analysis of these cases, ${ }^{25}$ but the main recurring threads can still be highlighted.

\subsection{Essentiality or specificity?}

One issue to highlight is that in practice, distinguishing of the essentiality and specificity requirement has not been evident. In Czechia v. Commission, for instance, the General Court merged the two requirements, finding that the Commission had not modified an essential element of the legislation at issue because it had respected the specificity requirement. ${ }^{26}$ On appeal, the Court corrected the General Court on this point and clearly distinguished the two. ${ }^{27}$ To determine whether the essentiality requirement was respected, the Court engaged in a bottom up, rather than top down (cf. supra) approach: Czechia had argued that the Commission had modified essential elements of the Intelligent Transport Services Directive because the Commission had required Member States to establish independent monitoring bodies. The Court assessed the merits of Czechia's plea by first looking at the type of powers which the Commission required the monitoring bodies to have (rather then to look at what qualifies as defining a policy in this area) and concluded that since the bodies only had monitoring (and no real enforcement powers), ${ }^{28}$ no essential elements were in play. Squaring the circle, this meant that no political choices which require "the conflicting interests at issue to be weighed up on the basis of a number of assessments" 29 were in play either.

The difficulty in distinguishing essentiality and specificity is also clear from the pleas invoked by parties and the ratio decidendi of the Courts. Indeed, it seems that both parties and the Courts are more comfortable with framing question of delegation

\footnotetext{
${ }^{24}$ Joined Cases C-124/13 and C-125/13, Parliament \& Commission v. Council, ECLI:EU:C:2015:790, para. 50.

${ }^{25}$ For an analysis of some of these cases, see Merijn Chamon, 'Limits to Delegation under Article 290 TFEU - The Specificity and Essentiality Requirements Put to the Test', (2018) 25 Maastricht Journal of European and Comparative Law 2, pp. 231-245.

${ }^{26}$ See Joined Cases T-659/13 and T-660/13, Czechia v. Commission, ECLI:EU:T:2015:771, paras 72-73.

${ }^{27}$ Case C-696/15 P, Czechia v. Commission, ECLI:EU:C:2017:595, paras 79-80.

${ }^{28}$ Ibid., para. 86.

${ }^{29}$ Ibid., para. 78.
} 
in terms of essentiality rather than specificity. Two cases in point that can be mentioned here are Dyson v. Commission ${ }^{30}$ and Paris/Bruxelles/Madrid v. Commission. ${ }^{31}$ In the first case, the legislator had adopted a directive requiring electrical appliances to bear energy labels that reflect their actual energy consumption and had left the Commission the power to adopt delegated acts setting out the methodology to determine the correct energy label for each appliance. When it comes to vacuum cleaners however, the Commission required the electric consumption of vacuum cleaners to be calculated while in operation with empty receptacles. Dyson argued that the delegated act was unlawful since it resulted in incorrect energy labels (as vacuum cleaners are typically used with half empty/full receptacles). In Paris/Bruxelles/Madrid v. Commission the Commission, following the Dieselgate scandal, had adapted the methodology to determine whether certain cars complied with the relevant Euro emission standards. In its new methodology however, the Commission had included a multiplier which effectively increased the acceptable levels resulting in a standard that was higher than the one laid down in legislation. Again, the applicants argued that the Commission had therefore acted unlawfully.

While these cases again, cannot be discussed in detail, it is interesting to point out that the Court of Justice, in the first case, and the General Court, in the second case, ruled that the Commission had breached the essentiality requirement. In Dyson $v$. Commission, the Court found that "the requirement [that the information supplied to consumers must reflect energy consumption while the machine is in use] is an essential element of the directive." ${ }^{2}$ In Paris/Bruxelles/Madrid v. Commission, the General Court held that the exhaust limits constitute essential elements which the Commission could therefore not de facto amend. ${ }^{33}$ These qualifications seem remarkable since the legal problem in both cases does not seem to concern the essentiality requirement but, instead, seem to turn around the Commission not respecting the specificity requirement: the point of the delegation from the legislator to the Commission in both cases was to ensure that certain technical characteristics of the goods in question would be properly and accurately quantified: how much electricity does this household appliance consume in normal use? How much nitrogen oxide (and other hydrocarbons) may a car emit while it is operating in normal conditions? By devising methodologies that result in information that does not reflect normal use or that does not contribute to lowering emissions, the Commission breached the objectives for which a power was delegated to it (specificity) rather than the essentiality requirement. This distinction is not a mere legal nicety as the General Court's ruling in the second case demonstrates: because the Commission had de facto amended an essential element, the General Court ruled that the Commission had acted ultra vires. Under Article 263 TFEU this corresponds to the ground for annulment of lack of competence which is of public order and which the judge must assess of its own motion. A breach of the specificity

\footnotetext{
${ }^{30}$ Case C-44/16 P, Dyson v. Commission, ECLI:EU:C:2017:357.

${ }^{31}$ Joined Cases T-339/16, T-352/16 and T-391/16, Paris, Brussels \& Madrid v. Commission, ECLI:EU:T: 2018:927.

${ }^{32}$ Case C-44/16 P, Dyson v. Commission, ECLI:EU:C:2017:357, para. 60.

${ }^{33}$ Joined Cases T-339/16, T-352/16 and T-391/16, Paris, Brussels \& Madrid v. Commission, ECLI:EU:T: 2018:927, paras 118 \& 128 .
} 
requirement may, in contrast, be conceptualized as a breach of a higher ranking rule, which goes to the internal legality of an act and which the Union judge must not verify of its own motion. Indeed, the repercussion of the General Court's finding, if not corrected in the pending appeal before the Court of Justice, would be that it would always have to check whether the Commission did not modify an essential element whenever Commission delegated (and implementing, cf. infra) acts are challenged.

\subsection{Implementing acts}

Differently from Article 290 TFEU, Article 291 TFEU does not indicate any immediate limits to the implementing powers that may be conferred on the Commission or the Council. The only real limit which can be inferred from Article 291 TFEU is that the Council and Commission can only 'implement' EU law but as noted above, the Court has defined 'implementation' in the sense of Article 291 TFEU rather vaguely. The post-Lisbon standard against which implementing acts must be tested can be found in the Eures Network case in which the Court largely relied on its pre-Lisbon case law rather than devising a standard from scratch. According to the Court: "it is settled case-law that, within the framework of the Commission's implementing power, the limits of which must be determined by reference amongst other things to the essential general aims of the legislative act in question, the Commission is authorised to adopt all the measures which are necessary or appropriate for the implementation of that act, provided that they are not contrary to it." 34 While Article 291 TFEU, contrary to Article 290 TFEU, does not prescribe the essentiality requirement, the Court also ruled that "in exercising an implementing power, the Commission may neither amend nor supplement the legislative act, even as to its non-essential elements." 35 That the Court did not devise a new standard from scratch is understandable, since the current implementing acts have their precursors in pre-Lisbon times but as the sections above explain, some pre-Lisbon implementing acts are now delegated acts. As a result, the Court should not transpose its pre-Lisbon case law on 'implementing acts' wholesale to the post-Lisbon 'implementing acts'. The fact that it did contributes to the problematic delimitation between delegated acts and (postLisbon) implementing acts (cf. infra).

\section{Delegated and implementing acts: control}

As noted above, the fact that the delegated and implementing acts fulfil different functions also results in different control regimes. ${ }^{36}$ Again as noted, because the conferral of implementing powers has repercussions on the vertical division of competences in the EU, control is exercised by Member States through comitology committees.

\footnotetext{
${ }^{34}$ Case C-65/13, Parliament v. Commission, ECLI:EU:C:2014:2289, para. 44.

35 Ibid., para. 45.

${ }^{36}$ Zdobnõh even claims that the different function of these two acts lies precisely in their different control regimes. See Dmitri Zdobnõh, 'Competition between articles 290 and 291 TFEU: what are these two articles about', in E. Tauschinsky and W. Weiß (eds.), The Legislative Choice Between Delegated and Implementing Acts in EU Law - Walking a Labyrinth, Cheltenham, Edward Elgar, 2018, pp. 42-64.
} 
Since the delegation of powers under Article 290 TFEU has horizontal implications, the Commission will be controlled by the Council and Parliament.

\subsection{Article 290 TFEU}

Under Article 290 TFEU the control may exist in two forms: both institutions may, independently from each other, block any draft delegated act by the Commission or they may, independently from each other, revoke a delegation granted to the Commission. An open question is whether the legislator, when delegating powers, may prescribe further control requirements. At least the text of Article 290 TFEU itself seems to suggest that further requirements are indeed possible. ${ }^{37}$ So far however, neither the Council or the Parliament has ever revoked a delegation. Also the power to object to (or veto) a draft is seldomly used. At the time of writing Parliament and Council only exercised the right to object on 15 occasions. ${ }^{38}$

Clearly Article 290 TFEU does not explicitly foresee the control of Member States (through committees) which led the Commission to claim that the Lisbon Treaty had excised comitology from the process of adopting delegated acts. ${ }^{39}$ The reaction of the Member States in Council has been twofold: firstly, the Council has succeeded in de facto reintroducing comitology in the procedure for adopting delegated acts. Secondly the Council has resisted completely aligning the pre-Lisbon legislation granting implementing powers to the Commission to the Lisbon legal framework.

\subsubsection{Re-introducing comitology}

With the entry into force of the Lisbon Treaty, the Commission was quick to note that it would not need to submit its draft delegated acts to institutionalised committees of national experts. Instead, the Commission announced that it would systemically consult expert groups composed of Member States' experts (often in the very same composition as the formal comitology committee competent in the substantive field concerned) but only in a consultative role. ${ }^{40}$ In the subsequent years, the Member States in Council successfully pushed for a formalization of this consultation. A Common Understanding on Delegated Acts was annexed to the 2016 Interinstitutional agreement on better law-making and it prescribes mandatory consultations of Member States' experts, whereby the latter are given sufficient time to study the drafts of the Commission which is required to explain how it will take into account

\footnotetext{
${ }^{37}$ This is also the position of the Parliament, see Resolution of 5 May 2010 on the power of legislative delegation, OJ [2011] C 81E/6, point 3. Contra, see the Council Legal Service Opinion on the Application of Arts. 290 (delegated acts) and 291 (implementing acts) TFEU, 11 April 2011, 8970/11, point 20. An argument in favour of the control mechanisms in Article 290 TFEU constituting an exhaustive list may be found in the travaux préparatoires of the constitutional treaty. During the Convention an additional control mechanism had been suggested but not retained. See the Presidency's 'Projet d'articles 24 à 33 du Traité constitutionnel', 26/02/2003, CONV 571/03, p. 7.

${ }^{38}$ This information is available on the register of delegated and implementing acts, see https://webgate.ec. europa.eu/regdel/\#/home.

${ }^{39}$ See the Guidelines for the services of the Commission on Delegated Acts, SEC(2011)855, para. 86.

${ }^{40}$ See European Commission, COM(2009) 673 final, pp. 67.
} 
the experts' views and which must give the experts an opportunity to react to possible amendments of the draft delegated acts subsequent to their initial tabling. ${ }^{41}$ This effectively results in a 'comitology light' procedure that is reintroduced for delegated acts. $^{42}$

\subsubsection{The ongoing alignment to the Lisbon legal framework}

To understand the second way in which the Member States have frustrated the partial abolishment of comitology, it is necessary to recall that pre-Lisbon implementation (in the broad sense) was governed by comitology, i.e. also those acts which amended legislative acts. One of the procedure used for this was the regulatory procedure with scrutiny (PRAC) which was introduced in 2006, mainly at the request of the Parliament given that the Constitutional Treaty (which would have introduced the delegated act) would not immediately enter into force. The PRAC was specifically used to amend or supplement acts adopted pursuant to the co-decision procedure. It was a typical comitology procedure (involving Member States experts) that also gave the Council and Parliament a veto right over drafts (much like Article 290 TFEU does now). Unlike the other pre-Lisbon comitology procedures, it could not be replaced in a horizontal manner (cf. infra) since most of the references to the PRAC in existing legislation needed to be changed into references to a delegated power. This required updating every single reference to the PRAC in an ad hoc manner. The Commission in 2011 had envisaged that this review process would be concluded by the end of the $7^{\text {th }}$ parliamentary term in $2014 .{ }^{43}$ Yet more than 6 years later, the review process is still ongoing. The three initial legislative proposals by the Commission to align the existing PRAC references to the new Lisbon reality ${ }^{44}$ remained in limbo in the Council which objected to a wholesale alignment to delegated acts. The Commission withdrew these in 2015 and proposed a new alignment after the IIA on Better Lawmaking. ${ }^{45}$ While the IIA should have facilitated the alignment process (since the Member States in Council now had certainty that delegated acts would be adopted pursuant to a comitology light procedure), the process has not been finalized yet. At the end of the $8^{\text {th }}$ parliamentary term, a partial alignment was adopted, ${ }^{46}$ with the hardest cases left for a new Parliament to agree on together with the Council. That more than ten years after the entry into force there is still legislation in force that refers to a pre-Lisbon comitology procedure ${ }^{47}$ is the result of the Council's prefer-

\footnotetext{
${ }^{41}$ See part II of the Common Understanding between the European Parliament, the Council and the Commission on Delegated Acts, OJ [2016] L 123/1.

${ }^{42}$ Carlo Tovo, 'Delegation of Legislative Powers in the EU: How EU Institutions Have Eluded the Lisbon Reform', (2017) European Law Review 5, pp. 689-693.

${ }^{43}$ See the statements by the Commission annexed to the comitology regulation, OJ [2011] L 55/19.

${ }^{44}$ See $\operatorname{COM}(2013) 451$ final; $\operatorname{COM}(2013) 452$ final; and COM(2013) 751 final.

${ }^{45}$ See COM(2016) 798 final; $\operatorname{COM(2016)~} 799$ final.

${ }^{46}$ See Regulation 2019/1243 of the European Parliament and of the Council adapting a number of legal acts providing for the use of the regulatory procedure with scrutiny to Articles 290 and 291 of the Treaty on the Functioning of the European Union, OJ [2019] L 198/241.

${ }^{47}$ This issue has also come before the Court. For a discussion, see Merijn Chamon, 'Dealing with a Zombie in EU Law - The Regulatory Comitology Procedure with Scrutiny', (2016) 23 Maastricht Journal of European and Comparative Law 4, pp. 714-724.
} 
ence to rely on implementing acts (or acts adopted pursuant to comitology), whereas the Parliament wants to see the PRAC references changed into references to Article 290 TFEU.

\subsection{Article 291 TFEU}

Unlike under Article 290 TFEU, the comitology system was fully retained under Article 291 TFEU. Differently from Article 202 EC however, Article 291(3) TFEU prescribes that the horizontal comitology instrument is to be adopted pursuant to the ordinary legislative procedure. This greatly strengthened the position of the Parliament, which is i.a. illustrated by the fact that post-Lisbon the implementation of the Common Commercial Policy (which pre-Lisbon did not come under the horizontal comitology regime) has also been subjected to the standard comitology rules. ${ }^{48}$ The comitology regulation ${ }^{49}$ replaces the second comitology decision and automatically aligns the latter's procedures to the new ones of the regulation. It thus prescribes that references in existing legislation to the old advisory procedure are to be read as references to the regulation's advisory procedure and that references to the management or regulatory procedure are to be read as references to the examination procedure. ${ }^{50}$ As noted above, the only procedure which has not been automatically aligned is the PRAC.

Control over the Commission is exercised by the comitology committees established under secondary legislation. The relevant legislation will also determine through which procedure the committee will exercise control. In practice, most comitology committees act under the examination procedure, which gives the greatest control to national representatives. Indeed, under the advisory procedure the committee acts by simple majority and gives a non-binding opinion, whereas under the examination procedure the committee acts pursuant to qualified majority and may force the Commission to reconsider a draft implementing act or to submit it to the Appeal Committee in case of a negative (or sometimes no) opinion. The exact procedure is laid down in Articles 5 to 6 of the regulation but can also be graphically summarized as in Fig. 2.

Apart from Article 11, which gives the Parliament and Council a droit de regard, no formal role is foreseen anymore for the Council. Unlike under some of the procedures of the second comitology decision, a committee cannot refer a file anymore to the Council. While the Appeal Committee convenes at an appropriate level (as per recital 7 to the regulation), which may be the level of ministers, a formal role for the Council has been excised. Remarkably enough, the Commission in 2017 itself

\footnotetext{
${ }^{48}$ For a discussion, see Jacques Bourgeois \& Merijn Chamon, 'The Integration of EU Trade Defence in the Horizontal Comitology Regime', in: Michael Hahn \& Guillaume Van der Loo (eds), Law and Practice of the Common Commercial Policy - The first 10 years after the Treaty of Lisbon, Leiden, Brill, 2020, pp. 512-530.

${ }^{49}$ Regulation 182/2011 of the European Parliament and of the Council laying down the rules and general principles concerning mechanisms for control by Member States of the Commission's exercise of implementing powers, OJ [2011] L 55/13.

${ }^{50}$ See Article 13(1) of the comitology regulation.
} 
proposed to re-introduce a role for the Council through an amendment of the comitology regulation. ${ }^{51}$ Amongst others, the Commission proposed an explicit option to have the Appeal Committee convene at ministerial level and for the Commission to formally ask the opinion on certain files. The Commission did so in an attempt to break the deadlock in which a number of typical files find themselves in the comitology procedures: decisions on the authorisation of genetically modified organisms or pesticides typically do not garner a QMV for or against in either the committee or the Appeal Committee. This means that the Commission is left to adopt the decision in these sensitive cases but the Commission dreads having to take the political responsibility for these decisions. While other elements in the Commission's 2017 proposal are to be lauded (changing the voting rules in the Appeal Committee and making the votes in the Appeal Committee public), the proposal to reintroduce a formal role for the Council seems fundamentally misguided. ${ }^{52}$

While normally a comitology procedure will apply whenever the Commission exercises powers pursuant to Article 291(2) TFEU, this is not always the case. ${ }^{53}$ Sometimes, especially in the area of the CAP and fisheries, the EU legislator will confer an implementing power on the Commission while explicitly noting that " $[\mathrm{t}]$ hose powers should be exercised without applying Regulation (EU) No 182/2011." " Under the comitology regulation this indeed seems possible since its Article 2(1) provides that a "basic act may provide for the application of the advisory procedure or the examination procedure". 55 There would therefore seem to be an option to prescribe (or not) a comitology procedure. Under EU primary law however this practice appears problematic. As noted above, when the Commission exercises an implementing power it exceptionally fulfils a function for which the Member States are the default actors, which explains why it is the Member States that will then exercise a control function. By not prescribing a comitology procedure however, the EU legislator denies the Member States the right to control how the Commission exercises its implementing powers. ${ }^{56}$

Finally, when exceptionally it is the Council that is empowered under Article 291 TFEU, no specific (political) control mechanisms are foreseen. Indeed, the legal basis for the comitology regulation only refers to "mechanisms for control by Member States of the Commission's implementing powers".

\footnotetext{
${ }^{51} \mathrm{See} \operatorname{COM}(2017) 85$ final. On this proposal, see also Antoine Buchet, 'La réforme des pouvoirs conférés à la Commission européenne, entre métamorphose et réminiscence', (2018) 54 Cahiers de droit européen 1, pp. 240-241.

${ }^{52}$ There does not seem to be much appetite among the legislators to pursue this proposal and it is to be expected that the Parliament will not accept that the Commission only foresees a strengthening of the Council's role. The report of the rapporteur of the legal affairs committee indeed goes in this direction. See Report of 12 October 2020 by MEP Szájer, A9-0187/2020.

${ }^{53}$ I would like to thank Irina Tanasescu for drawing my attention to the extent of this practice.

${ }^{54}$ See e.g. Recital 15 of Regulation 2016/2336 of the European Parliament and of the Council establishing specific conditions for fishing for deep-sea stocks in the north-east Atlantic and provisions for fishing in international waters of the north-east Atlantic, OJ [2016] L 354/1.

${ }^{55}$ Emphasis added.

${ }^{56}$ Clearly this is less of a problem at a practical level, since a majority of the Member States will have voted in favour of foregoing the application of a comitology procedure in the Council.
} 


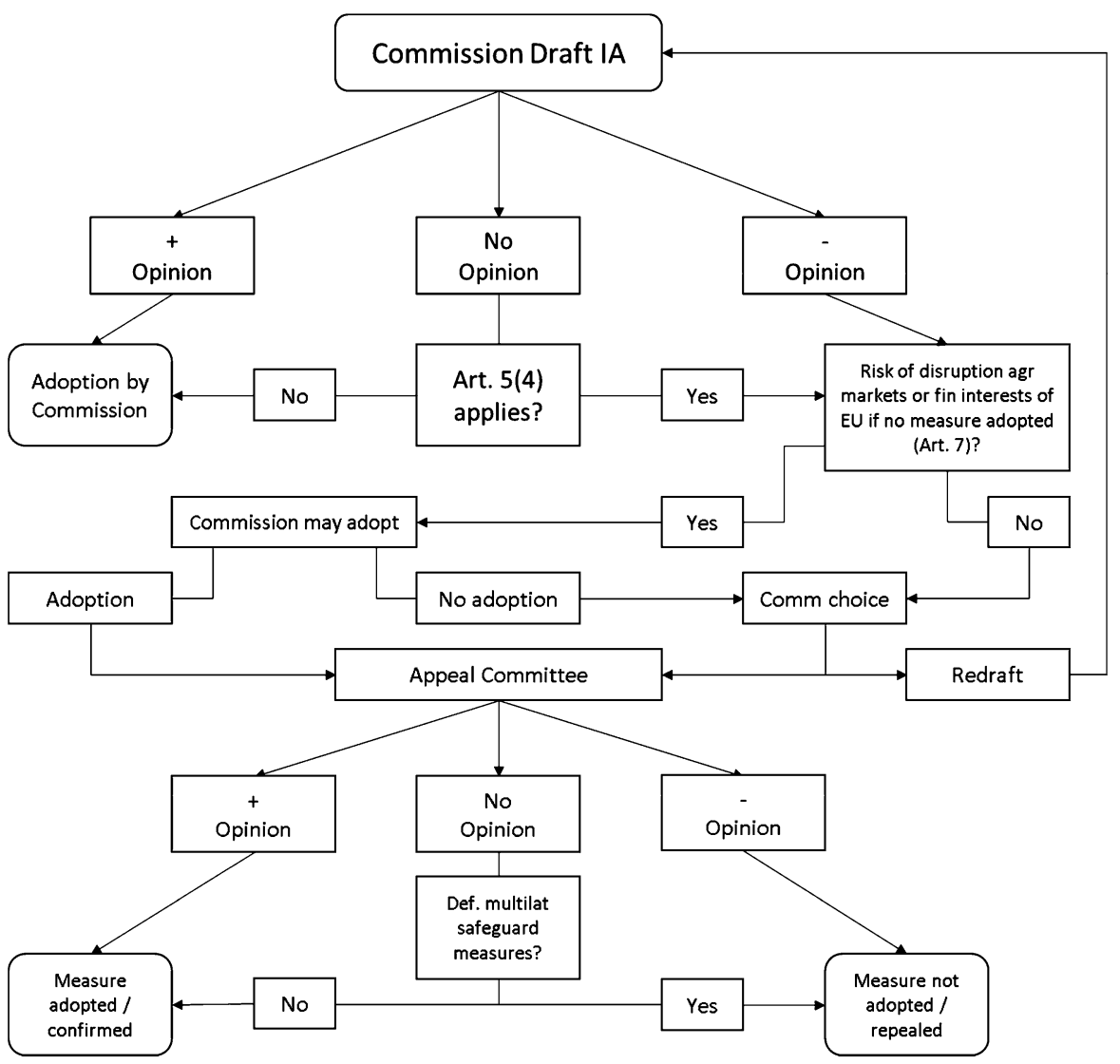

Fig. 2 The examination procedure

\section{Delegated and implementing acts: delimitation}

As noted above, the conceptual distinction between delegated and implementing powers is obfuscated because of their overlapping functions. While the meaning of 'amendment' in Article 290 TFEU is clear enough, there is a potential overlap between the notions of supplementation (in Article 290 TFEU) and implementation (in Article 291 TFEU). As noted, these functions both came under the broad preLisbon notion of implementation. This problematic overlap is also illustrated by the comitology regulation's automatic alignment of the comitology procedures: under the second comitology decision, the regulatory procedure was to be used 'to adapt or update non-essential provisions of a basic instrument'. ${ }^{57}$ Post-Lisbon, this is a function which only a delegated act can fulfil, yet the comitology regulation has automatically aligned the regulatory procedure to the examination procedure. Thus, both in function and procedure the new delegated and implementing acts appeared to be overlapping.

${ }^{57}$ See Article 2(b) of Council Decision 1999/468 laying down the procedures for the exercise of implementing powers conferred on the Commission, OJ [1999] L 184/23. 
While the Commission had initially tried to convince the Court to erect an impermeable wall between the two types of acts, the Court, in two judgments in 2014 and $2015^{58}$ has confirmed that the legislator has a discretion in empowering the Commission either under Article 290 or 291 TFEU, as long as the basic requirements spelled out in the relevant provision are met. ${ }^{59}$ The idea that an implementing power may be distinguished from a delegated power because the Commission would have a greater discretion when exercising the latter was thereby also explicitly rejected by the Court. ${ }^{60}$ Differently from its ruling in $S B C$ on the delimitation between legislative and non-legislative acts, the Court thus left this issue to the political institutions. While this may be understandable, it has also resulted in very protracted legislative negotiations: since the choice is ultimately to the legislators to decide which power is delegated/conferred, and because the Parliament has a clear preference for delegated acts while the Council has a preference for implementing acts, significant time and energy is each time invested in the trilogues in reaching an agreement on the type of power which will be granted to the Commission. To smoothen this process, the institutions in 2019 agreed on a number of criteria, guiding the choice between granting implementing or delegated powers. ${ }^{61}$ However, not only are the criteria non-binding, they are also rather disappointing in terms of substance: some criteria simple repeat what is already explicitly prescribed in the Treaties, other criteria explicitly recall that certain measures (such as authorizations) can be adopted in the form of a legislative act, a delegated act or an implementing act. Whether the 2019 IIA will facilitate future legislative negotiations thus remains to be seen.

\section{The non-exhaustiveness of the framework established in Articles 290 and 291 TFEU}

As noted above, the framework established in Articles 290 and 291 TFEU does not exhaustively regulate the exercise of executive rule-making powers at the EU level. This is already clear from the text of the Treaties, given the numerous legal bases providing for autonomous executive powers. After the entry into force of the Lisbon Treaty the Court of Justice's jurisprudence revealed further areas of executive rulemaking. Thus, in Short-selling the Court of Justice confirmed that EU agencies may be empowered to adopt acts of general application. The UK's argument that such a power would undermine the framework laid down in Articles 290 and 291 TFEU was

\footnotetext{
${ }^{58}$ Case C-427/12, Commission v. Parliament \& Council, EU:C:2014:170; Case C-88/14, Commission v. Parliament \& Council, EU:C:2015:499.

${ }^{59}$ For instance, there is no choice if the legislator wants to empower the Commission to adopt individual decisions, since delegated acts can only be of general application. Likewise, there is no choice if the legislators want to empower the Commission to amend its legislation, since that has to be done through a delegated act.

${ }^{60}$ Case C-88/14, Commission v. Parliament \& Council, EU:C:2015:499, para. 32. The General Court had earlier held that this was a distinguishing element. See Joined Cases T-659/13 and T-660/13, Czechia v. Commission, ECLI:EU:T:2015:771, para. 47.

${ }^{61}$ See the IIA on Non-Binding Criteria for the application of Articles 290 and 291 of the Treaty on the Functioning of the European Union, OJ [2019] C 223/1.
} 
not accepted by the Court, since the agency and the national authorities concerned "have a high degree of professional expertise and work closely together in the pursuit of the objective of financial stability within the Union." ${ }^{2}$ While the Court's findings in Short-selling appear questionable in light of the principle of institutional balance (the Court arguably not sufficiently protecting the Commission's prerogatives under Articles 290 and 291 TFEU), its ruling suggests that executive powers which require a high degree of specific expertise constitute a category separate from those in Articles 290 and 291 TFEU and thus need not be granted to the Commission or Council but may be exercised by subsidiary bodies such as EU agencies. ${ }^{63}$

Also the Court's judgment in Spain v. Council revealed a further area of executive powers which is not governed by Articles 290 and 291 TFEU. In that case Spain challenged a fine imposed on it by the Council under the Stability and Growth Pact. Before deciding on the merits of the case, the Court had to determine whether it had jurisdiction or whether the case should have been lodged before the General Court, since the latter has jurisdiction, under Article 51 of the Statute, to hear cases against implementing measures adopted by the Council pursuant to Article 291(2) TFEU. The Court held that the power in question was an implementing power but that Article 291(2) TFEU had to be read together with Article 291(1) TFEU. The Court then found that "Article 291(2) TFEU relates solely to legally binding acts of the European Union which lend themselves in principle to implementation by the Member States, like those to which Article 291(1) TFEU refers, but which, in contrast to the latter acts, must, for a particular reason, be implemented by means of measures adopted not by each Member State concerned, but by the Commission or the Council, for the purpose of ensuring that they are applied uniformly within the European Union."64 Since Member States would not be able to impose fines on themselves (pursuant to Article 291(1) TFEU), the Council adopting such fines cannot then be presumed to be acting under Article 291(2) TFEU. In the case at hand this meant that the Court of Justice confirmed its jurisdiction to hear the case, whereas this finding's broader repercussions are that the Commission's and Council's implementing powers are not exhaustively governed by Article 291(2) TFEU. ${ }^{65}$

\section{Some open questions}

Finally, there are many open questions only some of which can be flagged here but without being analysed in detail. A first such question is what the limits are to the Council's (and the Commission's) autonomous executive powers. Are the Council

\footnotetext{
${ }^{62}$ Case C-270/12, UK v. Parliament \& Council, ECLI:EU:C:2014:18, para. 85.

${ }^{63}$ For a more elaborate discussion, see Merijn Chamon, 'Beyond Delegated and Implementing Acts: Where do EU Agencies Fit in the Article 290 and 291 Scheme?', in W. Weiß and E. Tauschinsky (eds.), The Legislative Choice between Delegated and Implementing Acts in EU Law, Cheltenham, Edward Elgar, 2018, pp. 174-199.

${ }^{64}$ Case C-521/15, Spain v. Council, EU:C:2017:982, para. 48.

${ }^{65}$ For a discussion, see Merijn Chamon, 'Fining Member States under the SGP, or how enforcement is different from implementation under Article 291 TFEU: Spain v. Council', (2018) 55 Common Market Law Review 5, pp. 1495-1520.
} 
and Commission barred from regulating essential elements when exercising these powers? This does not a priori flow from Article 290 TFEU since the latter only regulates the relationship between legislative and delegated acts. In Eures Network, the Court expanded this to implementing acts (under Article 291 TFEU) but transposing this to the autonomous executive acts does not seem straightforward, especially if the legal basis conferring an autonomous executive power is entirely self-standing. ${ }^{66}$ In Multiannual Cod Plan, the Court at least confirmed that the limits to the Council's power under such legal bases are not the same as the limits to its implementing power derived from Article 291(2) TFEU. ${ }^{67}$

Another question is precisely when the threshold for exceptionally granting an implementing power to the Council is met. Pre-Lisbon Article 202 EC provided that the Council could reserve implementing powers to itself in specific cases but Article 291(2) TFEU provides that this is only exceptionally so and in duly specified cases. The threshold has thus arguably been raised but so far there is no post-Lisbon guidance of the Court on this point. Under the Court's pre-Lisbon jurisprudence the Council was required to give reasons why implementing powers were granted to the Council rather than the Commission. ${ }^{68}$ Even this minimal threshold does not always seem to be met in the post-Lisbon era, when the Council reserves implementing powers to itself. 69

A further issue on which there is only pre-Lisbon guidance from the Court is the choice between different comitology procedures. Article 2 of the comitology regulation gives guidance as to the choice between the advisory and the examination procedure, ${ }^{70}$ begging the question which discretion the legislator has to deviate from the prescribed procedure. In the Life and Forest Focus cases, which related to the second comitology decision, the Court held that the legislator needs to motivate its choice if it deviates from the default procedure. ${ }^{71}$

Finally, there is the question whether the comitology rules can be invoked by private parties. Clearly, both the rules in the comitology regulation and, a fortiori, the internal rules of procedure of the comitology committees aim to structure the way in which Member States may control the exercise of implementing powers by the Commission. This does not mean however that they are not of relevance to private parties.

\footnotetext{
${ }^{66}$ In this regard it may be noted that the legal bases at issue in Multiannual Cod Plan and Slovakia \& Hungary v. Council are paired with a legal basis prescribing a legislative procedure (Articles 43(3) and 78(3) TFEU follow the legislative legal bases of Articles 43(2) and 78(2) TFEU). In those cases, one could still make an argument that the legislator has to define the overall policy but this is not an option of the legal basis conferring an autonomous executive power is self-standing like Article 31 TFEU.

${ }^{67}$ Joined Cases C-124/13 and C-125/13, Parliament \& Commission v. Council, ECLI:EU:C:2015:790, para. 54.

${ }^{68}$ See Case C-257/01, Commission v. Council, ECLI:EU:C:2005:25, para. 51.

${ }^{69}$ See e.g. recital 114 of Regulation 806/2014 of the European Parliament and of the Council establishing uniform rules and a uniform procedure for the resolution of credit institutions and certain investment firms in the framework of a Single Resolution Mechanism and a Single Resolution Fund, OJ [2014] L 225/1.

${ }^{70}$ It may be noted here that the Commission's original proposal provided for binding criteria, see Article 2 in the proposal COM(2010) 83 final.

${ }^{71}$ See Case C-378/00, Commission v. Parliament \& Council, ECLI:EU:C:2003:42; Case C-122/04, Commission v. Parliament \& Council, ECLI:EU:C:2006:134.
} 
Such a party might indeed want to invoke an alleged procedural irregularity to challenge the legality of an implementing act adversely affecting its interests. In Tilly Sabco, the Court confined itself to noting that at least Article 3(3) of the comitology regulation constituted an essential procedural requirement, respect of which it could assess out of its own motion. ${ }^{72}$ The Court therefore did not have to address the question whether a private party is entitled to raise alleged violations of that provision. In addition, there is the question whether this extends to the internal rules of procedures of the committees (and not just provisions of the comitology regulation itself) and whether there is an obligation on the Court to raises such procedural irregularities out of its own motion.

Publisher's Note Springer Nature remains neutral with regard to jurisdictional claims in published maps and institutional affiliations.

Open Access This article is licensed under a Creative Commons Attribution 4.0 International License, which permits use, sharing, adaptation, distribution and reproduction in any medium or format, as long as you give appropriate credit to the original author(s) and the source, provide a link to the Creative Commons licence, and indicate if changes were made. The images or other third party material in this article are included in the article's Creative Commons licence, unless indicated otherwise in a credit line to the material. If material is not included in the article's Creative Commons licence and your intended use is not permitted by statutory regulation or exceeds the permitted use, you will need to obtain permission directly from the copyright holder. To view a copy of this licence, visit http://creativecommons.org/licenses/by/4.0/.

${ }^{72}$ Case C-183/16 P, Tilly Sabco v. Commission, ECLI:EU:C:2017:704, para. 116. 